\title{
Tantangan dan Peluang Bagi Millenial di Era Revolusi 4.0 Dalam Bidang Perpajakan di SMK Negeri 2 Baubau, Kota Baubau, Sulawesi Tenggara
}

\section{Rudi Abdullah}

Program Studi Manajemen, Fakultas Ekonomi, Universitas Muhammadiyah Buton

rudiazra9140@gmail.com

\begin{abstract}
Abstrak
Generasi millenial sangat erat kaitannya dengan Revolusi Industri 4.0. Dampak dari revolusi industri 4.0 terhadap perpajakan di Indonesia sangat berpengaruh terhadap layanan pajak berbasis aplikasi yang merupakan sebuah tantangan dan peluang. SMK Negeri 2 Baubau banyak terdapat kaum millennial yang sangat aktif menggunakan internet. Hal itu sangat mudah untuk siswa-siswa SMK Negeri 2 Baubau untuk mempelajari perpajakan di revolusi industri 4.0 dan mampu mengikuti perkembangannya dalam dunia kerja. PKM ini diadakan secara online dengan memberikan sosialisasi tantangan dan peluang di era revolusi industri 4.0 dalam bidang perpajakan berbasis aplikasi . PKM dihadiri oleh dua puluh delapan (28) siswa kelas XII dan dewan guru. PKM ini berhasil menumbuhkan semangat dan rasa keingintahuan siswa untuk lebih mendalami dan mempelajari tentang perpajakan dalam era revolusi industri 4.o. Dengan adanya praktek pengabdian ini, semoga siswa-siswi dan pihak sekolah mendapatkan ilmu dan wawasan yang lebih luas lagi mengenai tantangan dan peluang di era revolusi industri 4.0 di bidang perpajakan.
\end{abstract}

Kata Kunci: perpajakan, industri 4.0, tantangan, peluang

\section{Pendahuluan}

Perkembangan teknologi dalam era Revolusi Industri 4.0 atau dikenal dengan istilah generasi ke-4 Revolusi industri dimana memiliki hubungan yang sangat erat dengan generasi milenial atau dikenal dengan generasi Z. Lahirnya era revolusi industri 4.0 ini memberikan perubahan yang besar dalam masyarakat hampir disemua aspek kehidupan yang mengarah pada otomatisasi dan digitalisasi hampir disemua sektor. Perubahan yang terjadi hari ini tidak disadari secara penuh oleh banyak pihak terutama pada kalangan siswa dan juga pendidik, hal ini adalah tantangan khususnya dalam dunia pendidikan terutama generasi milenial/muda. Kondisi ini membawa dampak yang sangat luas dan nyata langsung di alamai dalam kehidupan sehari-hari. Contoh yang paling nyata adalah saat kita melakukan pesanan makanan, hanya cukup klik aplikasi Go Food dengan menggunakan Handphone cerdas, saat kita ingin pergi cukup klik Go Jek atau Go Grab hanya dengan mengunakan aplikasi yang sudah tersedia di Hand phone, dimana aplikasi ini semua ada dalam satu aplikasi tapi memiliki fitur yang mendukung untuk kegiatan kita sehari-hari. OECD (2017) dalam risetnya menekankan bahwa sistem perpajakan harus bertransformasi dan berubah secara berkesinambungan 
menyesuaikan dengan pesatnya kemajuan teknologi dan digitalisasi, serta perkembangan pola bisnis". Penggunaan aplikasi android dengan menggunakan handphone cerdas pada dasarnya akan terjadi peningkatan pajak yang sangat efektiv dan efisien bahkan bisa terjadi penurunan biaya serta mendorong sukarela para wajib pajak untuk meningkatkan investasi dan pertumbuhan ekonomi, hal inilah yang menjadi tujuan utama dengan adanya sistem digitalisasi.

Menurut OECD (2017), sistem perpajakan di era digital yang ideal adalah yang memenuhi kriteria yaitu terhubung secara global (globally connected), mumpuni secara teknologi (technologically enabled), kolaboratif dan terintegrasi (collaborative and integrated), mengutamakan data dan wawasan (data and insight led), manajemen kepatuhan informasi yang lebih baik (better informed compliance management), memiliki sumber daya manusia yang mumpuni (enabled workforce), dan terakhir, melanjutkan transformasi dan terus berubah secara signifikan mengikuti tren teknologi digital dan bisnis termutakhir". Dampak dari revolusi industry 4.0 terhadap perpajakan di Indonesia sangat berpengaruh, dimana hampir semua layanan pajak berbasis elektronik dimana mulai dari e-registration, e-filing, e-biling dan e-faktur dimana semua aplikasi ini bisa di lakukan oleh para wajib pajak. Dengan adanya revolusi industry 4.0 wajib pajak yang ingin membuat NPWP tidak harus antri datang ke kantor pelayanan pajak terdekat melainkan dapat mendaftar melalui internet (Abdullah, 2021). Dalam proses beberapa waktu NPWP akan diantar ke alamat tujuan wajib pajak.

Siswa/l yang belajar pada SMK Negeri 2 Baubau banyak yang aktif dalam memakai internet dimana hampir semua adalah generasi milenial. Mata pelajaran perpajakan yang di pelajari oleh mahasiswa/i SMK Negeri 2 Buabau menjadi sangat mudah untuk dipahami. Siswa-Siswi SMK Negeri 2 Baubau kelas XII Jurusan Akuntansi sebetulnya sudah mempelajari perpajakan di kelas mereka, Pembelajaran yang dilakukan perlu dilakukan pengembangan terhadap materi yang sudah diperoleh di bangku sekolah. Perkembangan perpajakan hari semua pendidik terutama guru di tuntut untuk memberikan pengetahuan yang lebih tentang pelajaran ini. Dengan adanya cara pembelajaran yang maksimal maka hal ini tentu akan bedampak positif dimana hal ini akan memberikan kemudahan bagi para siswa/i SMK Negeri 2 Baubau dalam memasuki ataupun bersaing dalam mendapatkan pekerjaan di dunia kerja.

Dengan latar belakang diatas, Program Studi Manajemen S-1 Fakultas Ekonomi Universitas Muhammadiyah Buton membentuk Tim Pengabdian Kepada Masyarakat melakukan pengabdian dengan mitra yaitu SMK Negeri 2 Baubau, Kota Baubau Sulawesi Tenggara kepada Siswa kelas XII yang berfokus pada sosialisasi tentang Tantangan dan Peluang Bagi Millennial di Era Revolusi Industri 4.0 dalam Bidang Perpajakan. Harapannya para millennial mampu menghadapi tantangan pada era revolusi industry 4.0 dalam bidang berpajakan. Selain dari pada itu dapat menjadikan revolusi industry 4.0 adalah peluang untuk menciptakan hal-hal baru yang belum pernah ada sebelumnya dan juga hal ini memberikan kemudahan bagi para siswa/i SMK Negeri 2 Baubau dalam bersaing dibursa kerja dan dapat diserap didunia kerja. Tujuan dari Pelaksanaan Pengabdian Kepada Masyarakat yang di lakukan oleh Tim PkM Program Studi Manajemen Fakultas Ekonomi Universitas Muhammadiyah Buton yang dilaksanakan di SMK Negeri 2 Baubau yaitu untuk membantu siswa/i dalam menghadapi tantangan dan peluang diera revolusi industri khususnya perpajakan. Manfaat yang diperoleh oleh 
siswa/i SMK Negeri 2 Baubau dari adanya Pengabdian kepada Masyarakat ini yaitu mampu bersaing dalam memasuki dunia kerja.

\section{Metode Pelaksanaan}

Pengabdian Kepada Masyarakat ini mengambil objek Siswa-siswi SMK Negeri 2 Baubau, Jl. Gajah Madha RT.04/o2 Lamangga, Kelurahan Katobengke, Kecamatan Betoambari, Kota Baubau Sulawesi Tenggara dengan Kode Pos 93725. Seluruh Siswa/i ini mengambil Jurusan Akuntansi dan berada pada kelas XII. Pelaksanaan Pengabdian Kepada masyarakat ini dilaksanakan pada tanggal 28 Desember 2020 secara online karena adanya Pandemic global Corona Virus-19 melalui aplikasi Zoom Meeting, yang berfokus pada ruang lingkup meningkatkan pengetahuan tentang revolusi industri 4.0 dalam bidang perpajakan kepada siswa/i SMK Negeri 2 Jurusan akuntansi kelas XII dimana mereka memiliki mata pelajaran perpajakan. Adapun kegiatannya yaitu dengan memberikan sosialisai tentang tantangan serta peluang revolusi industri 4.0 dalam bidang perpajakan untuk siswa/i SMK Negeri 2 kelas XII jurusan akuntansi Lamangga, Kota Baubau.

Dalam Pelaksanaan pengabdian masyarakat yang dilakukan oleh Tim Program Studi Manajemen Fakultas Ekonomi Universitas Muhammadiyah Buton, terdapat beberapa tahapan dalam melaksanakannya yaitu:

1. Tahap perencanaan dimana yang dilakukan adalah meliputi survey awal dimana dilakukan di SMK Negeri 2 Baubau, lamangga, kelurahan katobengke, kecamatan betoambari Kota Baubau Sulawesi tenggara, Indonesia.

2. Pelaksanakan pengabdian kepada masyarakat ini dilaksanakan di SMK Negeri 2 Baubau yang bertempat di SMK 2 Baubau sebagai Hosting dan siswa/i menggunakan Handphone masing-masing dari rumah dalam kegiatan ini.

3. Melakukan Pemetaan terhadap siswa/i yang berada di SMK Negeri 2 Baubau, Lamangga, Kelurahan ketobengke Kecamatan Betoambari Kota Baubau dimana Jumlah siswa/i dimana dilanjutkan dengan melakukan pemetaan lokasi kegiatan serta mempersiapkan sasaran yaitu siswa/i sebanyak 30 orang, penelitian ini dianggap berhasil jika peserta yang hadir di atas $80 \%$.

4. Melakukan penyusunan bahan dan materi sosialisasi yang meliputi powerpont Presentation serta makala untuk kegiatan dalam Pengabdian kepada Masyarakat.

5. Tahap Pelaksanaan sosialisasi tantangan dan peluang revolusi industri 4.0 dalam perpajakan pada Siswa/i SMK Negeri 2 Kota Baubau, Lamangga dilaksanakan melalui metode sosialisasi dengan memberikan penjelasan tentang pelatihan perpajakan melalui internet dan pendampingan untuk membuat NPWP (Nomor Pokok Wajib Pajak) melalui internet, metode sosialisasi ini dilanjutkan dengan metode tanya jawab antara pemateri dengan peserta sosialisasi.

\section{Hasil dan Pembahasan}

Pelaksanaan acara berjalan seperti yang direncanakan. Pelaksanaan yang dimulai dengan pembukaan, kemudian disambut dengan penyampaian sambutan dari ketua PKM dan Perwakilan dari sekolah. Pelaksanaan pengabdian kepada Masyarakat ini 
memiliki tujuan yaitu membantu siswa/i untuk siap mengahadapi tantangan dan peluang di era revolusi industri saat ini khususnya dibidang perpajakan, sehingga siswa-siswi dapat bersaing ketika mereka memasuki dunia kerja.

Kegiatan penyuluhan ini diikuti oleh 30 peserta yang terdiri siswa-siswi kelas XII SMK Negeri 2 Kota Baubau, dewan guru dan panitia Pengabdian kepada Masyarakat dimana terdiri dari dosen dari program studi Manajemen dan Program Studi Akuntansi Fakultas Ekonomi Universitas Muhammadiyah Buton. Semua yang mengikuti kegiatan Pengabdian Kepada Masyarakat adalah peserta dimana mengikuti materi dengan baik dalam hal pemaparan dan pada waktu tanya jawab peserta sangat antusias terlihat dari banyaknya pertanyaan dari peserta dimana sesi ini digunakan untuk melakukan pertanyaan antara lain bagaimana cara melaporkan pelaporan pajak secara online dan apakah NPWP wajib bagi seluruh warga negara indonesia dan manfaatnya untuk apa. Dalam kegiatan ini peserta di bekali ilmu dan pengetahuan dalam menghadapi tantangan dan peluang di era revolusi industri 4.0. Diharapkan siswa-siswi siap bersaing dan menghadapi kehidupan di era revolusi saat ini dengan penuh percaya diri sehingga dapat menghasilkan karya yang inovatif dan dapat bersaingan dengan yang lain.

Pemateri memberikan pengetahuan seputar pajak kepada peserta penyuluhan agar dapat mengetahui tantangan dan peluang perpajakan dalam revolusi industri 4.0 saat ini dengan lebih baik. Dan peserta diberikan pemahaman sebagai berikut:

\section{Perkembangan Pajak di Era Revolusi Industri 4.0}

Perkembangan industri yang mengarah ke tren yang menjadi otomatis dan perusahaan yang bergerak dalam bidang teknologi terutama dalam pertukaran data pada pabrik biasa dikenal dengan istilah Industri 4.o. perkembangan teknologi dimana didalamnya berisi data siber-fisik, sistem cloud dan sistem viber. Dengan adanya sistem otomatisasi ini membuat kopian dunia secara fisik virtual sehingga dalam mengambil keputusan tidak hanya mengacu melalui internet. Pajak sebagai komponen dalam mata rantai bisnis dan ekonomi yang tak terpisahkan harus siap, cepat dan tanggap dalam merespon dampak era Revolusi industri 4.0 ini. sistem, proses dan produk perpajakan berbasis teknologi yang maju dan mumpuni (Malik, 2021).

Sistem perpajakan di Indonesia sebenarnya sudah memulai di masa goan awal, Dimana perkembangan sistem perpajakan melalui sistem yang baru atau lebih di kenal dengan New Payment Control System (NPCS) dan berkembang terus seiring waktu dan tuntutan. (Abdullah R. M., 2021) Pemetaan wajib Pajak pelayanan pendaftaran, pembayaran, pelaporan dan pemeriksaan pajak harus di kelola dalam satu basis teknologi informasi yang canggih dan terintegrasi, sehingga mampu mengefesiensikan tugas-tugas perpajakan itu sendiri tanpa mengabaikan prinsip prinsip perpajakan yang sudah ada sebelumnya.

Lima pilar Reformasi Pajak yang telah di canangkan termasuk di dalamnya adalah berkaitan dengan reformasi sistem informasi dan basis data serta proses bisnis, maka terciptalah pelayanan dan produk DJP yang secara berkesinambungan dimana teknologi informasi menjadi basis datanya terutama internet seperti, e-Registration, e-Faktur, eFilling, e-Billing, e-Bupot yang saat ini sudah mulai familiar di para wajib Pajak (Abdullah \& Dja'wa, 2019). Hal terebut manjadi bukti para stackholder dan otorisasi pajak kita dalam menyongsong era Revolusi Industri 4.0 
Soemitro (2011) menjelaskan bahwa pajak adalah iuran rakyat kepada kas negara berdasarkan undang-undang yangdapat dipaksakan dengan tidak mendapat jasa timbal yang langsung dapat ditunjukkan dan yang digunakan untuk membayar pengeluaran umum. Sedangkan menurut Ray (2003), pajak adalah suatu pengalihan sumber dari sektor swasta ke sektor pemerintah, bukan akibat pelanggaran hukum, namun wajib dilaksanakan berdasarkan ketentuan yang ditetapkan lebih dahulu, tanpa mendapat imbalan yang langsung dan proporsional, agar pemerintah dapat melaksanakan tugastugasnya untuk menjalankan pemerintahan.

\section{Industri 4.0}

Herman (2016) menyatakan bahwa sejarah dimulainya revolusi industri dimulai dari Revolusi Industri 1,0 dimana hal ini dilihat dari aktivitas manusia dalam perusahaan melakukan produksi dengan tujuan mendukung efektivitas serta efisiensi, Revolusi Industri 2,0 ditandai dengan perusahaan melakukan produksi barang secara masal dan adanya standar kualitas yang di tentukan, Revolusi Industri 3.0 dimulai dengan sistem robotic yang serba otomatis sehingga perusahaan fleksibel dalam produksi secara masal, dan Revolusi Industri 4.0 dimana yang terjadi adalah perusahaan secara kolaborasi dengan menggukan kecerdasan buatan.

Pemerintah Negara Jerman melakukan pendirian proyek dimana melakukan promosi tentang perusahaan yang menggunakan komputerisasi secara otomatis, hal inilah yang mengakibatkan munculnya istilah Revolusi Industri 4.o. Krajewski (2013) menjelaskan, industri 4.0 ditandai dengan peningkatan digitalisasi manufaktur yang didorong oleh empat faktor: faktor pertama peningkatan volume data, kekuatan komputasi, dan konektivitas; faktor kedua munculnya analisis, kemampuan, dan kecerdasan bisnis; faktor ketiga terjadinya bentuk interaksi baru antara manusia dengan mesin; dan faktor keempat perbaikan instruksi transfer digital ke dunia fisik, seperti robotika dan $3 \mathrm{D}$ printing.

\section{Tantangan dan Peluang}

Perubahan didunia bisnis secara fundamental dan sangat signifikan di zaman sekarang berawal dari pergeseran pola pikir dan pola perilaku manusia yang semuanya di sebabkan oleh Revolusi Industri. Keadaan ini dikenal dengan istilah disrupsi dimana mengakibatkan akan timbulnya ancaman bukan hanya dibidang ekonomi tetapi disemua bidang apabila hal ini tidak dilakukan pengelolaan secara baik dan benar. Pengalaman dari revolusi industri Pertama, Kedua dan ketiga, dapat dilihat terjadinya kemajuan di bidang teknologi dimana hal ini membuktikan keberhasilan dalam peningkatan pada lancarnya rantai pasok diperusahaan, peningkatan secara signifikan dimana secara efisien dan produktif. Menurut Weda (2018), banyak pekerjaan saat ini dapat diotomatisasi. Otomasi adalah hasil dari perkembangan teknologi yang difasilitasi oleh kemajuan data dengan volume besar (big data), sistem komputasi dan pemanfaatan mesin yang semakin canggih. Proses yang sedang terjadi ini, sangat berarti bagi manusia. Bagaimana kita bekerja dan hidup mengalami perubahan karena sekarang, kita memiliki akses ke sejumlah besar data yang dapat menginformasikan tentang hal-hal baru dan dapat memungkinkan mesin melakukan hal-hal baru itu.

Industri 4.0 menciptakan yang menimbulkan bergesernya, peranan, serta dampak yang harus mampu dipahami sehingga siswa/i dapat merancang metode bisnis sesuai 
Vol. 2, No. 2, Mei 2021

ISSN 2721-4834

dengan keadaan yang terjadi hari ini serta mudah untuk dipahami. Tantangan yang dihadapi oleh siswa/i yaitu bagaimana efisiensi dalam teknologi yang berpotensi ini bisa diwujudkan serta kemajuan dari teknologi ini menawarkan keuntungan bagi semua pengguna teknologi, selain itu juga ada konsekuensi lain yang akan terjadi dan harus dilakukan antisipasi terutama masalah perpajakan, hal tersebut dapat dilalui ketika para siswa/i menguasai perpajakan dan pelaporannya melalui sistem perpajakan berbasis aplikasi atau secara online.

Industri 4.0 dalam bidang perpajakan menjadikan tantangan dan peluang untuk siswa-siswi kedepannya, hal tersebut harus diperkuat dengan pengetahuan dan regulasi perpajakan dan penguasaan teknologi oleh siswa-siswi, agar ketika mereka memasuki dunia kerja mereka dapat beradaptasi dan menguasainya.

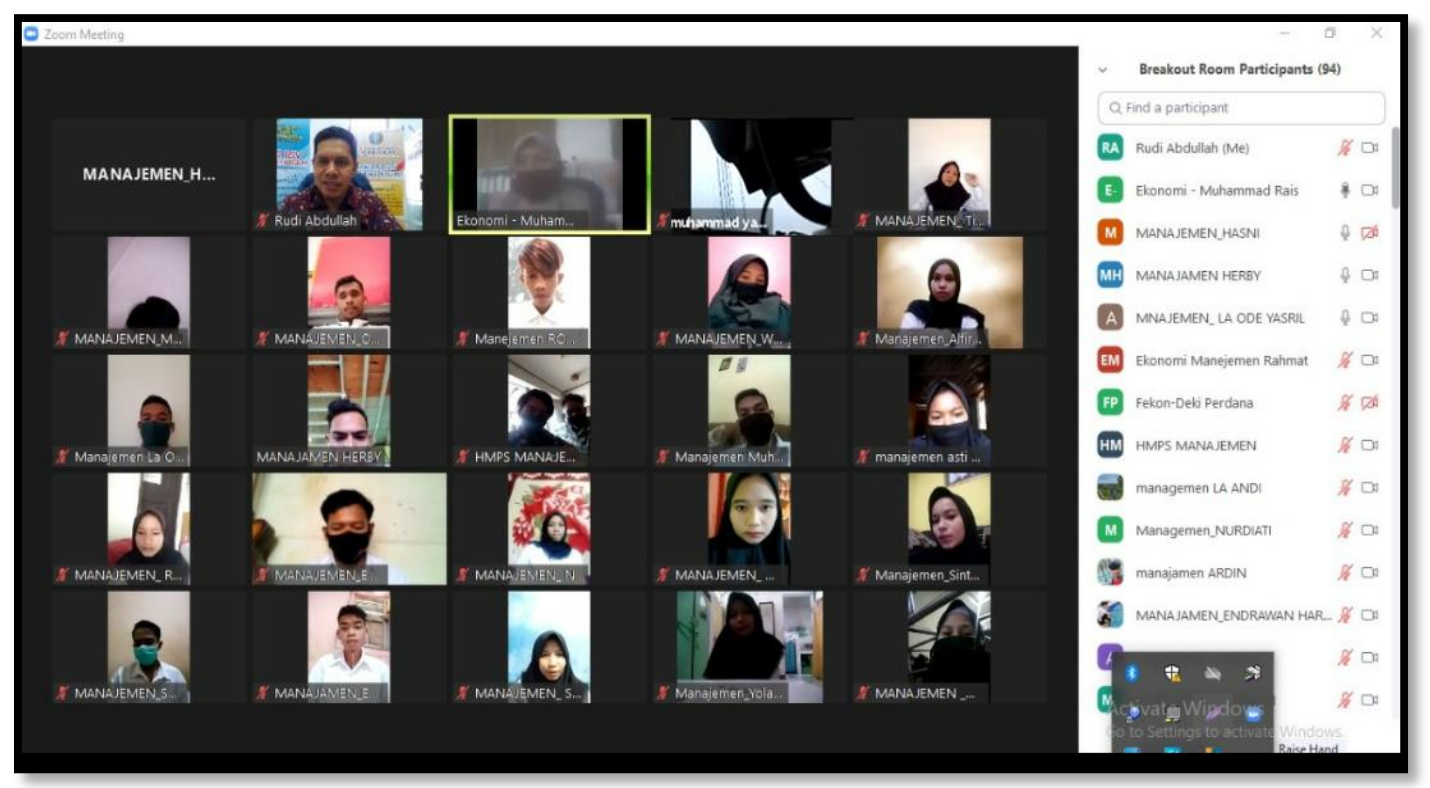

Gambar 1. Pengarahan, Pemberian Materi dan Sambutan Dekan Fakultas Ekonomi

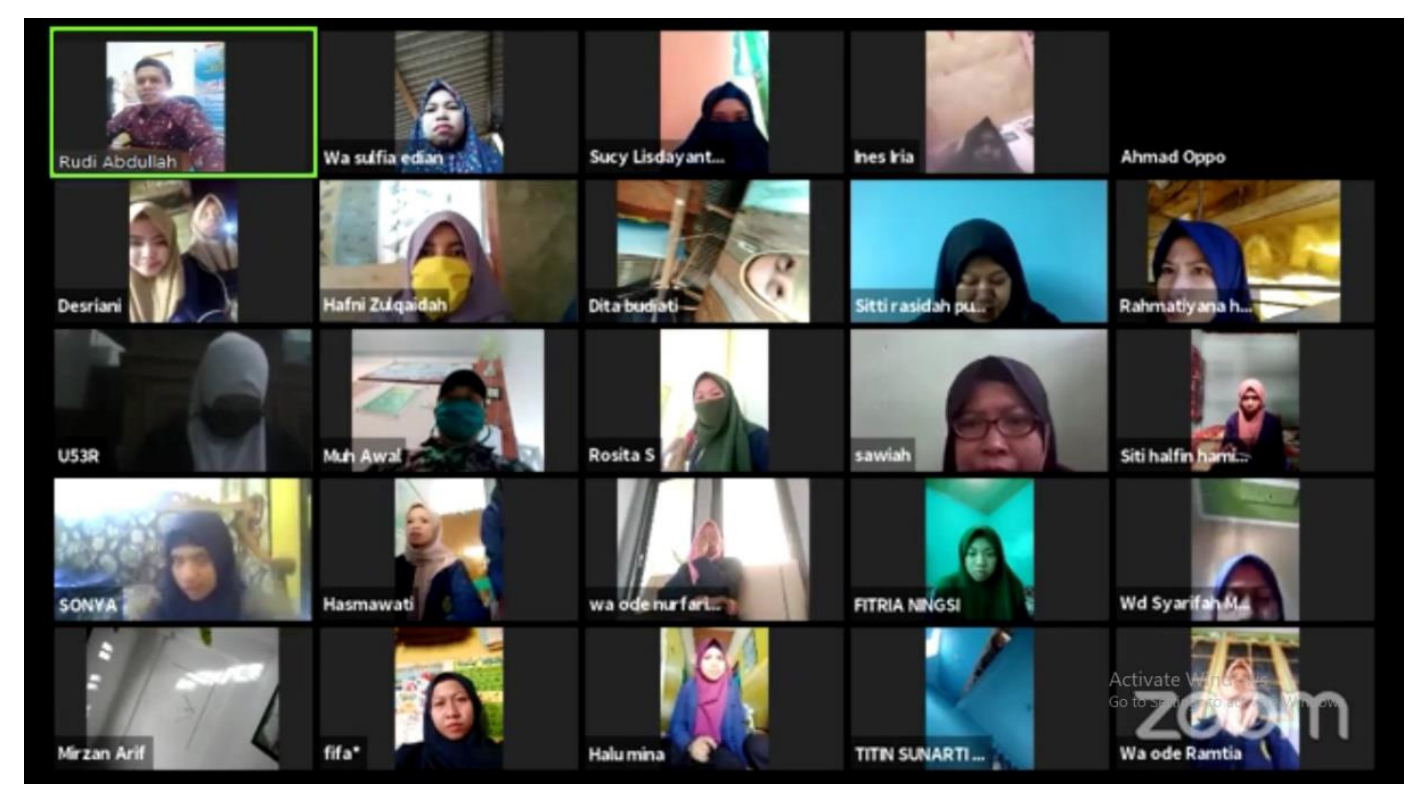

Gambar 2. Sambutan Ketua PKM dan Memberikan Materi Ke peserta 


\section{Kesimpulan}

PKM ini menghasilkan kesimpulan bahwa siswa/i di SMK Negeri II Kota Baubau Sulawesi Tenggara harus memiliki pengetahuan dan praktiknya tentang perpajakan serta kemampuan secara teknologi dalam revolusi industri 4.0 dimana menjadikan tantangan serta peluang ketika mereka nanti masuk dalam dunia kerja, dengan melihat dari pertanyaan serta semangat yang tinggi yang disampaikan pada saat diskusi. Meskipun demikian tetap harus ditumbuh kembangkan lebih lagi agar siswa-siswi diharapkan dapat bersaing dan siap dalam menghadapi era revolusi saat ini dengan penuh rasa percaya diri dengan kreatifitas dan inovasi yang mereka ciptakan.

\section{Ucapan Terimakasih}

Terima kasih Kepada Dekan Fakultas Ekonomi Universitas Muhammadiyah Buton, Tim Pengabdian Kepada Masyarakat Fakultas Ekonomi Universitas Muhammadiyah Buton, dan kepada Guru dan Siswa/l SMK Negeri 2 Baubau, Kota Baubau Sulawesi Tenggara.

\section{Referensi}

Abdullah, R., \& Dja'wa, A. (2019). Pelatihan Pengelolaan Keuangan Badan Keswadayaan Masyarakat (BKM) Di Kelurahan Lipu Kota Baubau Sulawesi Tenggara. Prosiding Konferensi Nasional Pengabdian Kepada Masyarakat dan Corporate Social Responsibility (PKM-CSR), (pp. 1494-1508). Surabaya.

Abdullah, R. (2021). Edukasi Literasi Keuangan Pasar Modal Syariah Pada Pengurus Badan Milik Desa di Kecamatan Kolese Kota Baubau. Jurnal Abdidas, 2 (2), 323-328.

Abdullah, R. M. (2021). Penerapan Strategi Pemasaran Sebagai upaya meningkatkan Usaha Kecil dan Menengah Di Desa Wawoangi Kec.Sampolawa Ditengah Pandemic Covid - 19. Community Development Journal: Jurnal Pengabdian Masyarakat, 76-80.

OECD. (2017). Sistem Perpajakan Di Era Digital.

Herman, M. P. (2016). Design Principles For Industrie 4.o Scenarios. Presented at the 49th Hawaiian International Conference on Systems Science. Hawai: Conference on Systems Science.

Krajewski, L. J. (2013). Operation Management "Process and Suply Chain". England: Global Edition, England: Pearson Education Limited.

Malik, E. A. (2021). Program Kemitraan Masyarakat Usaha Keripik Pisang di Desa Wawoangi Kecamatan Sampolawa. Community Development Journal: Jurnal Pengabdian Masyarakat, 72-75.

Ray, S. A. (2003). Manajemen Perrpajakan. Jakarta: Edisi Pertama Salemba Empat. Soemitro, R. (2011). Asas dan Dasar Pajak. Bandung: Rafika Aditama. Weda, S. (2018). Problematika Dunia Pendidikan di Era Revolusi Industri 4.0. Rappang: STKIP Muhammadiyah Rappang. 